\title{
Governing ethnic unrest: Political Islam and the Kurdish conflict in Turkey
}

\author{
Onur Günay and Erdem Yörük
}

\begin{abstract}
How can we explain the mass appeal and electoral success of Islamist political parties? What are the underlying sources of the Islamist political advantage? Scholars have provided numerous answers to these widely debated questions, variously emphasizing the religious nature of the discourses in Islamist movements, their ideological hegemony, organizational capacity, provision of social services, reputation, and structural factors. However, one key aspect of Islamist movements has been underexplored in the current literature; namely, Islamists' promises to resolve ethnic questions that remain unresolved in secularist nation-states. In this article, we argue that the extent to which Islamists govern ethnic unrest significantly shapes their electoral success and ability to establish broader hegemony. Based on ethnographic and sociological data, this article explores one particular recent electoral puzzle that reveals the limits of the scholarly literature on Islamist political advantage, examining the ethnic politics of the governing Justice and Development Party (Adalet ve Kalkinma Partisi, AKP) in Turkey.
\end{abstract}

Keywords: Political Islam; elections; ethnic politics; Turkey; Kurds

Department of Anthropology and Woodrow Wilson School of Public and International Relations, Princeton University, Princeton, New Jersey, USA, 08544; ogunay@princeton.edu.

Department of Sociology, Koç University, Rumelifeneri Yolu 34450, Sarıyer, İstanbul, Turkey; Department of Social Policy and Intervention, University of Oxford, Barnett House, 32-37 Wellington Square, Oxford OX1 2ER, UK; eryoruk@ku.edu.tr.

Authors' Note: We would like to express our gratitude to João Biehl, Elizabeth A. Davis, Julia Elyachar, Burak Gürel, and Ali Sipahi for their insightful comments. We also benefited greatly from the comments and suggestions of the article's anonymous reviewers, and we are thankful to them and to the editors of New Perspectives on Turkey for their editorial guidance. We are grateful to Konda Research and Consultancy for sharing their data with us. This study has been generously funded by the European Research Council, Grant No. 714868. 


\section{Introduction}

There has been immense scholarly interest in the mass appeal and electoral success of Islamist movements in the Muslim world. Scholars from various disciplines have offered various explanations for this multifaceted phenomenon, and indeed such a complex social phenomenon as Islamist success may admit of multiple explanations. ${ }^{1}$ Despite the abundance of interpretations, however, the current literature fails to explain temporal variations in popular support for Islamists. The purpose of this article is to contribute to the literature in this field by bringing the ethnic politics of Islamist movements into conversation with the existing explanations, thus helping us to better understand the temporal variation of Islamists' success. To this end, we explore the rapid changes in the electoral performance of the Justice and Development Party (Adalet ve Kalkınma Partisi, AKP) during the general elections held in June and November 2015. We argue that the success of the ruling AKP was conditioned by the party's capacity to govern ethnic unrest. Specifically, the AKP promised to resolve the Kurdish problem, initially through ethnic inclusion on the basis of Islamic solidarity and class-based populism, and later through repression and authoritarianism, appealing in each case to either Kurdish or nationalist Turkish constituencies. We deploy anthropological and sociological data and analyses to show that the success of Islamist mobilization and the political configuration of diverse electoral performances depend on the realization or failure of this promise.

\section{Ethnic politics: A missing link in the literature on Islamist political success}

The strong electoral performance of Islamists has convinced scholars from various disciplines that there is an "Islamist political advantage," whereby Islamists are uniquely positioned and equipped to garner greater popular support in comparison to other political movements. In explaining the rapid, parallel, and global rise of political support for Islamist parties and movements, scholars typically have referred to the anti-Western position of Islamic parties, the religious nature of Islamist movements' discourses, ideological hegemony, organizational capacity, provision of social services, reputation, and various structural factors, as well as the existence of a devout bourgeoisie.

The first group of explanations for Islamists' success builds on the discursive advantages, cultural repertoire, and ideological hegemony of Islamists.

1 See Tarek Masoud, Counting Islam: Religion, Class, and Elections in Egypt (Cambridge: Cambridge University Press, 2014). 
These explanations put forth that Islamists gained power because they presented themselves as a counterforce against Western hegemony. ${ }^{2}$ From this perspective, contemporary political Islam is not a revival of traditional Islamic values, but a product of modernity. ${ }^{3}$ Some scholars argue that Islamic politics attracts Muslims of different nations because the notion of an Islamic brotherhood erases national differences and provides a universal signifier - the ummah or Muslim community-in opposition to the alienating West. ${ }^{4}$ Others articulate a moderation hypothesis which asserts that a successful political moderation of radical claims enables Islamist parties to succeed in electoral politics. ${ }^{5}$ For some scholars, Islamists manage to successfully locate their political message within the community's cultural codes and norms without imposing an external ethos. ${ }^{6}$ Although these accounts have significant explanatory power, they risk essentialism ${ }^{7}$ and reduce Muslim voters to what Sadik J. al-Azm has called "Homo Islamicus," regardless of the historical and sociopolitical context. ${ }^{8}$

On the other hand, material explanations for the Islamist political advantage refer to growing poverty and inequality as the basis of the Islamists' success. By promising to herald an era of justice, equality, and welfare, political Islam is seen by many as a significant counterforce to neocolonialism and corrupt regimes. ${ }^{9}$

2 Bernard Lewis, "The Roots of Muslim Rage," The Atlantic 266, no. 3 (1990): 47-60; Nikki R. Keddie, "The Revolt of Islam, 1700 to 1993: Comparative Considerations and Relations to Imperialism," Comparative Studies in Society and History 36, no. 3 (July 1994): 463-487; Mohammed Ayoob, "Political Islam: Image and Reality," World Policy Journal 21, no. 3 (2004): 1-14; John L. Esposito, The Islamic Threat: Myth or Reality (Oxford and New York: Oxford University Press,1992), 77-118.

3 Olivier Roy, The Failure of Political Islam, trans. Carol Volk (London: I.B. Tauris, 1994); Christopher Houston, "Civilizing Islam, Islamist Civilizing? Turkey's Islamist Movement and the Problem of Ethnic Difference," Thesis Eleven 58, no. 1 (1999): 83-98.

4 Abdullah Al-Ahsan, Ummah Or Nation?: Identity Crisis in Contemporary Muslim Society (Leicester: The Islamic Foundation, 1992); Ali Mohammed Naqvi, Islam and Nationalism, trans. Alaedin Pazargadi (Tehran: Islamic Propagation Organization, 1984).

5 Manfred Brocker and Mirjam Künkler, "Religious Parties Revisiting the Inclusion-Moderation Hypothesis 1: Introduction," Party Politics 19, no. 2 (2013): 171-186; Sarah Wilson Sokhey and A. Kadir Yıldırım, "Economic Liberalization and Political Moderation: The Case of Anti-System Parties," Party Politics 19, no. 2 (2013): 230-255; Mehmet Gürses, "Islamists, Democracy and Turkey: A Test of the Inclusion-Moderation Hypothesis," Party Politics 20, no. 4 (2014): 646-653; Güneş Murat Tezcür, Muslim Reformers in Iran and Turkey: The Paradox of Moderation (Austin: University of Texas Press, 2010).

6 Jenny B. White, Islamist Mobilization in Turkey: A Study in Vernacular Politics (Seattle: University of Washington Press, 2002).

7 Edward Said, Orientalism (New York: Pantheon, 1978), 80; Lisa Wedeen, "Conceptualizing Culture: Possibilities for Political Science," American Political Science Review 96, no. 4 (December 2002): 713-728.

8 Sadik J. Al-Azm, "Is Islam Secularizable?" Journal for the Critical Study of Religion 2 (1997): 83-90.

9 Nazih Ayubi, Political Islam: Religion and Politics in the Arab World (London and New York: Routledge, 2003); Salwa Ismail, "The Paradox of Islamist Politics," Middle East Report 221 (2001): 34-39; Esposito, The Islamic Threat. 
Some argue that Islamism has replaced socialism as the new emancipatory ideology of the oppressed, working classes, and urban poor. ${ }^{10}$ For many scholars, non-state provision of social welfare is a critical platform through which Islamists appeal to the poor. As the neoliberal state has withdrawn economically, Islamists have effectively filled this vacuum with an extensive provision of goods and informal welfare services to those who could not afford them. ${ }^{11}$ In Indonesia, Malaysia, Pakistan, Turkey, Egypt, Algeria, and Palestine, Islamists spread wide networks of social provision for the poor, among whom they gained widespread popularity. ${ }^{12}$ The reasons behind the failure of Islamists' political competitors to fill the same void remain unexplained, leading many scholars to go on to explore the matter of organizational structure.

For many scholars, Islamists have superior organizational resources and capabilities as compared to other political groups, due to their well-developed physical infrastructure, local networks, cellular organization structure,

10 Jülide Karakoç, "The Failure of Indirect Orientalism: Islamic State," Critique 42, no. 4 (2014): 597-606; Gilles Kepel, Jihad: The Trail of Political Islam, trans. Anthony F. Roberts (Cambridge, MA: Belknap, 2002), 47; Carlos García-Rivero and Hennie Kotzé, "Electoral Support for Islamic Parties in the Middle East and North Africa," Party Politics 13, no. 5 (2007): 611-636; Yahya Sadowski, "Political Islam: Asking the Wrong Questions?" Annual Review of Political Science 9, no. 1 (2006): 215-240; Bryan S. Turner, "Class, Generation and Islamism: Towards a Global Sociology of Political Islam," The British Journal of Sociology 54, no. 1 (2003): 139-147.

11 Judith Harik, The Public and Social Services of the Lebanese Militias (Oxford: Centre for Lebanese Studies, 1994); Ismail, "The Paradox of Islamist Politics"; Asef Bayat, "Activism and Social Development in the Middle East," International Journal of Middle East Studies 34, no. 1 (2002): 128; Ziya Öniş, "The Political Economy of Turkey's Justice and Development Party," in The Emergence of a New Turkey: Democracy and the AK Parti, ed. M. Hakan Yavuz (Salt Lake City: University of Utah Press, 2006): 207-234; John Walsh, "Egypt's Muslim Brotherhood: Understanding Centrist Islam," Harvard International Review 24, no. 4 (2003), 32; Lisa Anderson, "Fulfilling Prophecies: State Policies and Islamist Radicalism," in Political Islam: Revolution, Radicalism or Reform, ed. J.L. Esposito (Boulder: Lynne Rienner, 1997): 17-32; Quintan Wiktorowicz, Islamic Activism: A Social Movement Theory Approach (Bloomington: Indiana University Press, 2004); Peter Mandaville, Global Political Islam (Oxford and New York: Routledge, 2010); Jane Harrigan and Hamed El-Said, Economic Liberalisation, Social Capital and Islamic Welfare Provision (Houndmills and New York: Palgrave Macmillan, 2009); Nancy Jean Davis and Robert V. Robinson, Claiming Society for God: Religious Movements and Social Welfare in Egypt, Israel, Italy, and the United States (Bloomington: Indiana University Press, 2012).

12 Saiful Mujani and R. William Liddle, "Muslim Indonesia's Secular Democracy," Asian Survey 49, no. 4 (2009): 575-590; Farish A. Noor, "Blood, Sweat and Jihad: The Radicalization of the Political Discourse of the Pan-Malaysian Islamic Party (PAS) from 1982 Onwards," Contemporary Southeast Asia: A Journal of International and Strategic Affairs 25, no. 2 (2003): 200-232; Ashutosh Misra, "Rise of Religious Parties in Pakistan: Causes and Prospects," Strategic Analysis 27, no. 2 (2003): 186-215; Jahangir Amuzegar, "The Ahmadinejad Era: Preparing for the Apocalypse," Journal of International Affairs 60, no. 2 (2007): 35-53; Öniş, "The Political Economy of Turkey's Justice and Development Party"; Brynjar Lia, The Society of the Muslim Brothers in Egypt: The Rise of an Islamic Mass Movement, 1928-1942 (Reading: Ithaca Press, 1998); Judith Miller, "The Challenge of Radical Islam," Foreign Affairs 72, no. 2 (1993), 43; Shaul Mishal and Avraham Sela, The Palestinian Hamas: Vision, Violence, and Coexistence (New York: Columbia University Press, 2006). 
committed cadres, and practices of self-financing. ${ }^{13}$ A devout bourgeoisie is a necessary component of Islamist success, as it provides substantial financial and network resources. ${ }^{14}$ As good organizers, successful Islamist parties have optimal combinations of internal party cohesion and effective strategies that allow them to better recruit the local mainstream elite. ${ }^{15}$ Moreover, Islamic party platforms function as informational shortcuts to Muslim voters and confer a political advantage whenever voters are uncertain about parties' economic policies. ${ }^{16}$ Recent works, however, suggest that the literature has overstated the organizational reach of the Islamists. Cammett and Luong pinpoint the Islamists' reputation for good governance-competence, trustworthiness, and purity-as the proximate cause for their political success in the streets and at the ballot box. ${ }^{17}$ However, their arguments do not allow for any distinction among different Islamist parties and candidates, nor do they explain the persistent electoral success of Islamist government parties following corruption scandals. For example, in Turkey, the AKP government increased its votes after the massive corruption scandals of 2013. Similarly, Masoud emphasizes the critical role of structural factors in shaping the social and political institutions in which Egyptian voters and political parties are embedded. ${ }^{18}$

One of the greatest problems of the current literature is its failure to account for change and variation in the popular support for Islamists over time and space. ${ }^{19}$ In this article, we emphasize one key factor that explains temporal and spatial variation in Islamist political advantage; namely, Islamist political

13 Ayubi, Political Islam; Anthony Shadid, Legacy of the Prophet: Despots, Democrats, and the New Politics of Islam (New York: Basic Books, 2002); Janine A. Clark, Islam, Charity, and Activism: Middle-Class Networks and Social Welfare in Egypt, Jordan, and Yemen (Bloomington: Indiana University Press, 2004); Wiktorowicz, Islamic Activism; Eric Trager, "The Unbreakable Muslim Brotherhood: Grim Prospects for a Liberal Egypt," Foreign Affairs 90, no. 5 (2011): 114-126; Mandaville, Global Political Islam; Guilain Denoeux, "The Forgotten Swamp: Navigating Political Islam," Middle East Policy 9, no. 2 (2002), 56.

14 Cihan Tuğal, Passive Revolution: Absorbing the Islamic Challenge to Capitalism (Stanford: Stanford University Press, 2009); Ziya Öniş, "The Political Economy of Islamic Resurgence in Turkey: The Rise of the Welfare Party in Perspective," Third World Quarterly 18, no. 4 (1997): 743-766; Seyyed Vali Reza Nasr, "The Rise of 'Muslim Democracy'," Journal of Democracy 16, no. 2 (2005): 13-27; Şebnem Gümüşçü and Deniz Sert, "The Power of the Devout Bourgeoisie: The Case of the Justice and Development Party in Turkey," Middle Eastern Studies 45, no. 6 (2009): 953-968.

15 Feryaz Ocakli, "Notable Networks: Elite Recruitment, Organizational Cohesiveness, and Islamist Electoral Success in Turkey," Politics \& Society 43, no. 3 (2015): 385-413.

16 Thomas B. Pepinsky, R. William Liddle, and Saiful Mujani, "Testing Islam's Political Advantage: Evidence from Indonesia," American Journal of Political Science 56, no. 3 (2012): 584-600.

17 Melani Cammett and Pauline Jones Luong, "Is There an Islamist Political Advantage?" Annual Review of Political Science 17 (2014): 187-206.

18 Masoud, Counting Islam.

19 Ibid. 
parties' promise to resolve existing ethnic questions. Although Islamists' ethnic politics have been mostly underexplored in the literature, we argue that it contributes significantly to Islamist political success in Muslim majority nationstates. Many secular nation-state governments have endeavored to tackle national independence movements and ethnic insurgencies, but most of them have failed. Islamists, on the other hand, have gained prominence in countries like Indonesia, Morocco, Iran, and Turkey by promising to resolve ethnic conflicts and include ethnic groups under the banner of Islamic solidarity and Muslim brotherhood.

The combination of rising Islamist parties and the existence of (an) ethnic question(s) is a broader pattern throughout the Muslim world. In Indonesia, the emergence of various Islamist political parties in governing coalitions has been accompanied by compromises to the Aceh ethnic movement in Sumatra. ${ }^{20}$ In Morocco, the local Justice and Development Party (Hizb al-Adala wa't-Tanmia), governed by moderate Islamists, has adopted both repressive and co-opting relations with the Polisario Front movement, which propagates the secession of Western Sahara. ${ }^{21}$ Similarly, in Iran, the Islamic regime has followed numerous twists and turns in its compromising and repressive approaches to the Kurdish minority. Most critically, the regional autonomy that the Kurds in Iran expected to gain before the revolution of 1979 and partially attained afterwards has contributed to the continuance of the Islamist regime. ${ }^{22}$ Despite these examples, the relation between the success of Islamist politics, its temporal variations, and ethnic questions has not

20 Edward Aspinall, Islam and Nation: Separatist Rebellion in Aceh, Indonesia (Stanford: Stanford University Press, 2009); Peter Chalk, "Separatism and Southeast Asia: The Islamic Factor in Southern Thailand, Mindanao, and Aceh," Studies in Conflict and Terrorism 24, no. 4 (2001): 241269; Damien Kingsbury, "The Free Aceh Movement: Islam and Democratisation," Journal of Contemporary Asia 37, no. 2 (2007): 166-189.

21 Anouar Boukhars and Ali O. Amar, "Trouble in the Western Sahara," The Journal of the Middle East and Africa 2, no. 2 (2011): 220-234; Pablo San Martin, "Nationalism, Identity and Citizenship in the Western Sahara," The Journal of North African Studies 10, no. 3-4 (2005): 565-592; James N. Sater, Morocco: Challenges to Tradition and Modernity (Oxford and New York: Routledge, 2009); Samuel J. Spector, "Negotiating Free Association between Western Sahara and Morocco: A Comparative Legal Analysis of Formulas for Self-Determination," International Negotiation 16, no. 1 (2011): 109-135; Maria João Barata and Valentina Bartolucci, "Delegitimisation of Identity as a Political Strategy: The Moroccan Official Discourse about the Polisario Front," SSRN (2009), http://papers. ssrn.com/sol3/papers.cfm?abstract_id=2362007.

22 Hashem Ahmadzadeh and Gareth Stansfield, "The Political, Cultural, and Military Re-Awakening of the Kurdish Nationalist Movement in Iran," The Middle East Journal 64, no. 1 (2010): 11-27; Nader Entessar, "The Kurds in Post冈revolutionary Iran and Iraq," Third World Quarterly 6, no. 4 (1984): 911-933; Hussein D. Hassan, "Iran: Ethnic and Religious Minorities," CRS Report for Congress, Order Code RL34021, https://fas.org/sgp/crs/mideast/RL34021.pdf; A. William Samii, "The Nation and Its Minorities: Ethnicity, Unity, and State Policy in Iran," Comparative Studies of South Asia, Africa and the Middle East 20, no. 1 (2005): 128-137; Tezcür, Muslim Reformers in Iran and Turkey. 
been thoroughly theorized in the existing literature through original empirical research. To fill this gap, we analyze the case of Turkey, focusing on the relation between Islamist parties' electoral success and their capacities to deal with the ethnic conflict.

\section{The AKP, ethnic politics, and the Kurds}

Resolving the Kurdish issue has been essential for the AKP to establish political hegemony, for a number of reasons. The Kurds constitute approximately 18 percent of Turkey's population and thus represent a critical electoral bloc. Kurdish uprisings in Turkey have always posed a significant threat to political stability, economic growth, and governmental legitimacy. The armed conflict between the 'Turkish army and the Kurdistan Workers' Party (Partiya Karkerên Kurdistanê, PKK) has cost over 40,000 lives and, by 2005, close to 170 billion USD, although these exact figures remain unknown. ${ }^{23}$ The AKP based its national hegemony on the realization of a broader neoOttomanist imperial project, whereby ethnic and national differences would be erased under the Islamic universalism of the ummab. Islamists in Turkey understood Kurdish suffering as a natural consequence of secular Turkish nationalism. They idealized the multicultural Ottoman past and the millet system in which the Turks, Kurds, and other Muslim groups were theoretically to be treated as equal members of the ummab. ${ }^{24}$ In this scenario, a Kurdish-Turkish peace agreement in Turkey would have convinced the Muslim population in Turkey and worldwide that the AKP could unite Muslims of various nations. The Islamists' promise that religion could bridge ethnonational differences between the Turks and the Kurds found both positive and critical responses. ${ }^{25}$ Past and current research on Turkish and Kurdish Islamist writers show that "Kurdish-Islamist writers tend to search for a 'space' for Kurdish ethnic distinctiveness within the framework of the suggested formula of ummah, the Islamic community of the faithful, while the position of the Turkish-Islamist writers leans heavily toward defending

23 Noah Arjamond, "Nobody Knows How Many Have Died in the Turkey-PKK Conflict," Medium, https:// bullshit.ist/nobody-knows-how-many-have-died-in-the-turkey-pkk-conflict-c09c49b131ee; see also Servet Mutlu, "The Economic Cost of Civil Conflict in Turkey," Middle Eastern Studies 47, no. 1: 63-80.

24 For a discussion on Turkey's foreign policy and the new nationalism in the AKP era, see Cenk Saraçoğlu and Özhan Demirkol, "Nationalism and Foreign Policy Discourse in Turkey under the AKP Rule: Geography, History and National Identity," British Journal of Middle Eastern Studies 42, no. 3 (2015): 301-319.

25 Christopher Houston, Islam, Kurds and the Turkish Nation State (Oxford and Gordonsville: Bloomsbury Academic, 2003); Zeki Sarıgil and Ömer Fazlıoğlu, "Religion and Ethno-Nationalism: Turkey's Kurdish Issue," Nations and Nationalism 19, no. 3 (2013): 551-571. 
the integrity of the Turkish state rather than to acknowledging a Kurdish ethnic distinctiveness." 26

Today, following the failure of the fragile peace process and the resurgence of war between the Turkish army and the PKK, "it is no longer possible to claim that [the] AKP has been successful in employing Islam as a tool of conflict resolution." 27 Recent research shows that Islamists-media outlets, politicians, and religious elites-are no better equipped to accommodate ethnic pluralism than their secular counterparts, ${ }^{28}$ and that Islam's role as a peacemaker has been overstated. ${ }^{29}$ Similar to the cases of Iran and Sudan, Islamists in Turkey have been shown to be no better at resolving such ethnonational problems. ${ }^{30}$ However, the existing literature on Islamist political mobilization in Turkey does not explain the variation in Kurdish support for Islamists. The reasons for the long-standing Kurdish support for Islamists, followed by its drastic decrease in June 2015, remain a puzzle that needs to be solved.

In the next section, we will define an electoral puzzle, thereby revealing the limits of the current literature. Then, we will elaborate on the political and socioeconomic reasons for Kurdish support for the AKP during the 2000s, as well as for this support's rapid decline in the June 2015 elections. Finally, in the last section, we will explain how the AKP substituted the loss of Kurdish support with nationalist Turkish votes in the snap elections held in November 2015. We will focus particularly on the role of ethnic politics in Islamist political mobilization. First of all, we will discuss the broader social and political context of these ethnic electoral realignments, and then we will focus empirically on İstanbul, where we collected our ethnographic and part of our quantitative data. Figure 1 below shows that İstanbul had strong national voting trends for the AKP and pro-Kurdish parties during the 2000s.

26 Ümit Cizre Sakallıoğlu, "Kurdish Nationalism from an Islamist Perspective: The Discourses of Turkish Islamist Writers," Journal of Muslim Minority Affairs 18, no. 1, (1998): 73-89. For a well-articulated discussion on the complex distinctions between statist Islamism, Kurdish Islamism, and Islamism in Turkey, see Houston, Islam, Kurds and the Turkish Nation State. Similarly, Gülay Türkmen analyzes the role of religious elites as potential peacemakers in such conflict zones and identifies a three-fold typology of religious and ethnic identities as conceptualized by these elites: 1) religio-ethnic; 2 ) ethno-religious; 3) religious; see Gülay Türkmen, "Negotiating Symbolic Boundaries in Conflict Resolution: Religion and Ethnicity in Turkey's Kurdish Conflict," Qualitative Sociology 41, no. 4 (2018): 569-591.

27 Gülay Türkmen-Dervişoğlu, "United in Religion, Divided by Ethnicity? Why Islam Fails as a Supranational Identity in Turkey" (PhD dissertation, Yale University, 2016).

28 Ibid.; Murat Somer and Gitta Glüpker-Kesebir, "Is Islam the Solution? Comparing Turkish Islamic and Secular Thinking toward Ethnic and Religious Minorities," Journal of Church and State 58, no. 3 (2016): 529-555.

29 Mehmet Gürses, "Is Islam a Cure for Ethnic Conflict? Evidence from Turkey," Politics and Religion 8, no. 1 (March 2015): 135-154.

30 Somer and Glüpker-Kesebir, "Is Islam the Solution?"; Mehmet Gürses and Nicolas Rost, "Religion as a Peacemaker? Peace Duration after Ethnic Civil Wars," Politics and Religion 10, no. 2 (2016): 1-24. 


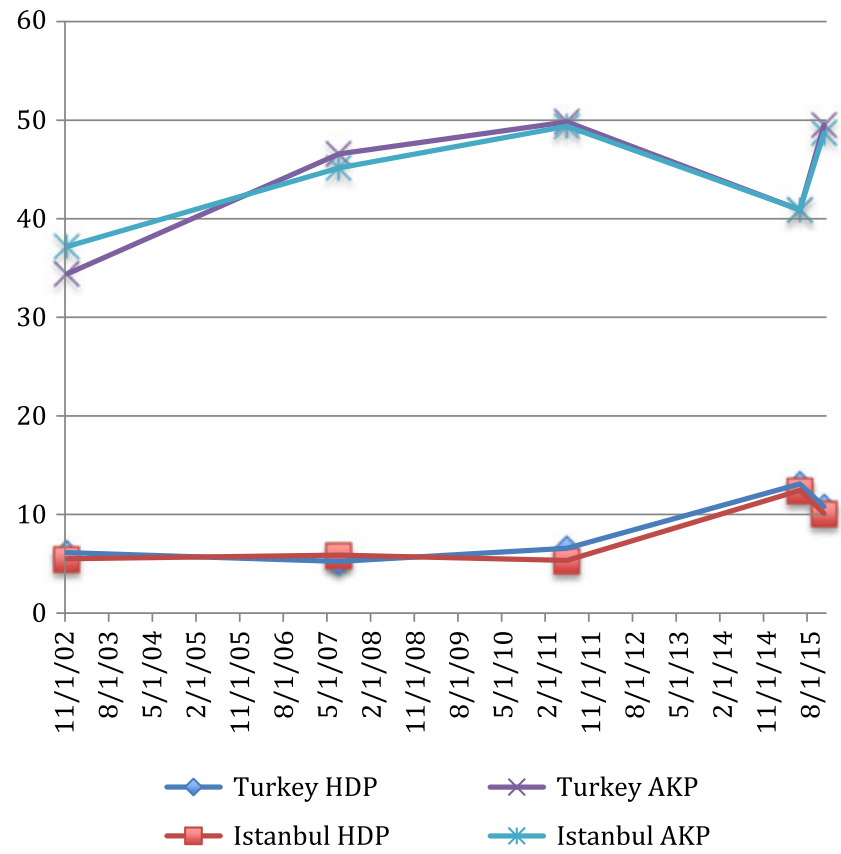

Figure 1. Voting trends for the AKP and pro-Kurdish parties in istanbul and Turkey in elections held in 2002, 2007, 2011, and 2015

Source: Supreme Election Council, Turkey

Nevertheless, we admit that Kurdish voting behaviors in İstanbul and in the Kurdish region were different. A thorough explanation for the latter would require an additional empirical analysis conducted on and in the Kurdish region, which is beyond the scope of this study. Still, although our claims regarding Kurdish voting patterns in İstanbul cannot be generalized out to the Kurdish region, they can give us significant insights into Kurdish political preferences in Turkey and their changing relation to political Islam and electoral politics. This is not only because around one-fifth of the Kurdish population in Turkey lives in İstanbul, but also because the movement of migrants between the Kurdish region and İstanbul helps to sustain a high degree of political synchronization among the Kurds living in these locations.

\section{Swing votes: An electoral puzzle}

Until recently, Turkey's AKP government was considered to be running a successful economy, emerging as a regional power, and implementing 

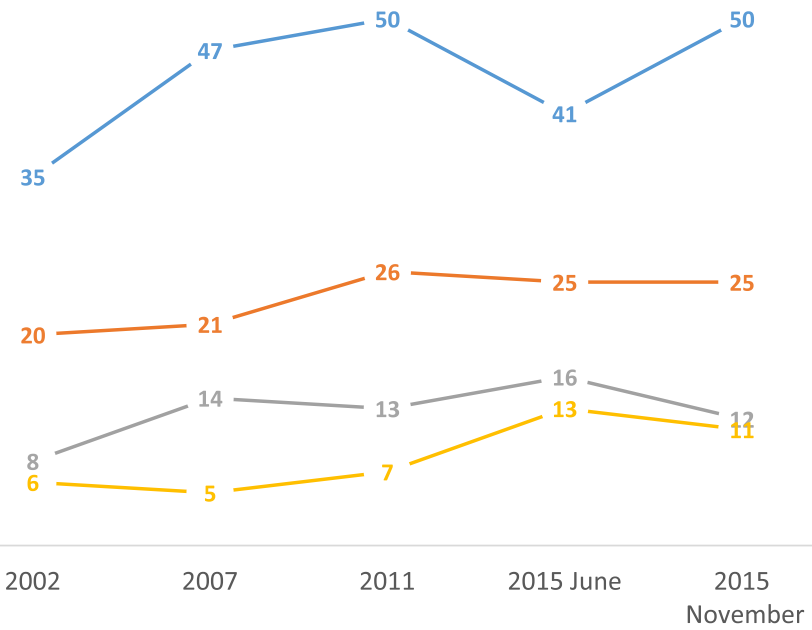

$--\mathrm{AKP}--\mathrm{CHP}--\mathrm{MHP}--\mathrm{HDP}$

Figure 2. Voting rates for major political parties in Turkey in elections held in 2002, 2007, 2011, June 2015, and November 2015

Source: Supreme Election Council, Turkey

authoritarian policies. It was also known for its uninterrupted single-party rule and expanding electoral support throughout the 2000s. However, the party experienced a dramatic fall (9 percentage points) in the June 2015 national elections, and then a sudden recovery in the early elections of November 2015, as shown in Figure 2 below.

In the June 2015 elections, the most important factor behind the AKP's decline was that one-fourth of the Kurdish votes in Turkey shifted from the AKP to the pro-Kurdish, left-wing People's Democratic Party (Halklarin Demokratik Partisi, HDP). Compared to the 2011 elections, the pro-Kurdish HDP doubled its vote share to gain 13.12 percent. The majority of new HDP votes came from the AKP in both the Kurdish region and in western metropolises such as İstanbul, though in different proportions. ${ }^{31}$

31 In İstanbul, AKP votes dropped by 520,000 while HDP votes increased by 600,000 . Meyersson points out that the HDP gained votes most importantly from the AKP. According to an IPSOS poll, 50 percent of those who voted for the HDP in 2015 voted for the previous pro-Kurdish party in the 2011 elections, with 22 percent voting for the AKP, 14 percent for other parties, and 13 percent being firsttime voters. This indicates an approximately 3 percent swing vote from the AKP to the HDP. According to an analysis by Talha Öz, of the 6.6 percent increase in HDP votes, approximately 4 percent came from the AKP. See Erik Meyersson, "How Turkey's Social Conservatives Won the Day for HDP," Erik Meyersson, June 8, 2015, http://erikmeyersson.com/2015/06/08/how-turkeys-socialconservatives-won-the-day-for-hdp/; Erik Meyersson, "Kinky Voting and Turkey's 'Sultans of Swing'," Erik Meyersson, November 9, 2015, http://erikmeyersson.com/2015/11/09/kinky-voting- 
The AKP government, which had previously been able to count on at least half of the Kurdish votes, lost its broad electoral hegemony with the realignment of its Kurdish constituency. However, in the November 2015 snap elections, the AKP managed to gain 49 percent of the votes cast, this time receiving support from Turkish nationalist voters in place of the lost Kurdish voters. What caused this abrupt swing vote between June and November, and what were the underlying sources of this Islamist electoral expansion, contraction, and re-expansion?

Our article will explain this electoral puzzle by unpacking the AKP's shifting strategy vis-à-vis the Kurds and answering three fundamental questions: First, why did the majority of Kurds in Turkey support the AKP through 2014? Second, why did Kurdish support for the AKP dramatically fall in June 2015? And third, how did the AKP mobilize the ethnic Turkish constituency between the June 2015 and the November 2015 elections? In answering these questions, we argue that the AKP utilized a repertoire of tactics and strategies in order to govern the long-standing Kurdish conflict through a combination of inclusion and repression (with the latter materializing with an abrupt authoritarian turn after the resurgence of war in July 2015).

We develop a synthesis of sociological and anthropological perspectives and methods to shed light on the complex interactions among the macro political and historical processes and everyday experiences that gave rise to the initial and long-standing Kurdish support for the AKP, its sudden shift away from the AKP electoral constituency, and its replacement by Turkish nationalist votes. We combine macro-level statistical data on elections, surveys, focus group discussions, and ethnographic data from Kurdish working-class neighborhoods in İstanbul so as to set up this micro-macro link and thereby analyze the ethnic politics of the AKP. By "ethnic politics," we mean the set of political practices, tactics, and strategies of governmental and non-governmental actors either directly or indirectly related to ethnic identities, cleavages, and conflicts.

Our macro-level sociological inquiry is based on existing quantitative analyses of the elections of June and November 2015, ${ }^{32}$ which describe the

and-turkeys-sultans-of-swing/; Talha Öz, "Vote Transitions in Turkish General Elections (2011-2015)," Talha Öz, June 9, 2015, http://talhaoz.com/?p=735; KONDA, "7 Haziran Sandık ve Seçmen Analizi," KONDA, June 2015, https://konda.com.tr/tr/rapor/7-haziran-sandik-ve-secmen-analizi/; KONDA, "1 Kasım Sandık ve Seçmen Analizi Raporu," KONDA, December 2015, https://konda.com.tr/tr/rapor/ 1-kasim-sandik-ve-secmen-analizi/; IPSOS, "2015 Genel Seçim Sandık Sonrası Araştırması," June 8, 2015, http://www.arastirmakutuphanesi.com/wp-content/uploads/2015/06/lpsos_SandikSonrasi_ CNNTURK-web2.pdf.

32 Meyersson, "How Turkey's Social Conservatives Won the Day for HDP"; Meyersson, "Kinky Voting"; Öz, "Vote Transitions in Turkish General Elections"; KONDA, "7 Haziran Sandık ve Seçmen Analizi"; KONDA, "1 Kasım Sandık ve Seçmen Analizi Raporu"; IPSOS, "2015 Genel Seçim Sandık Sonrası Araştırması." 
demographic and sociological profiles of party voters and vote shifts. In addition, we use descriptive statistical methods to analyze three sets of raw survey data from the research institutes KONDA and SAMER. ${ }^{33}$

Our ethnographic analysis relies on a two-and-a-half-year anthropological study conducted by Onur Günay between 2013 and 2016, which zeroed in on Kurdish migrant workers in a working-class neighborhood of İstanbul and entailed long-term participant observation. The study was grounded in participant observation with Kurdish workers who had fled political violence in the Kurdish region during the conflict-ridden 1990s as well as those seeking temporary work in İstanbul in the 2010s. The neighborhood of focus is slightly inland from İstanbul's upmarket business districts and is full of small factories, textile workshops, and bazaars. It is also home to the urban poor, working-class people with diverse ethnic origins, including displaced Kurds with heterogeneous political orientations. Moreover, the author's ethnographic research into a religious community of the Naqshbandi Sufi order (tarikat) during this period allowed us to further reflect on the Kurdish relation to religious orders and Islamist mobilization in everyday life. Most of the qualitative research material used in this article relies on more than 300 pages of fieldwork notes and 120 hours of recorded interviews conducted during the anthropological fieldwork. For the third part of the article, we conducted focus group discussions with Turkish nationalist and conservative voters in İstanbul in December 2016.

\section{Why did the Kurds support the AKP?}

In this section, we explain how the AKP gained political support from the majority of Kurds until late 2014. Figure 3 illustrates that after 2014, Kurdish votes swiftly moved from the AKP to the HDP, while between 2010 and 2014, the AKP was still getting the majority of Kurdish votes.

We argue that the AKP promised to include the Kurds into a larger society on both ethnic and class grounds. In this context, we will describe the following: (i) forms of class inclusion, such as social policies, anti-elitist mobilization, and clientelism and patronage networks; and (ii) forms of ethnic inclusion, such as membership in Islamic orders and the political opportunities created by the peace process.

33 The SAMER survey was conducted in İstanbul and İzmir in December 2013 and was based on a stratified, random sample of 3,944 informants; it was coordinated by one of the authors of the present article. KONDA provided us with their monthly survey raw data, each based on around 3,000 informants. 


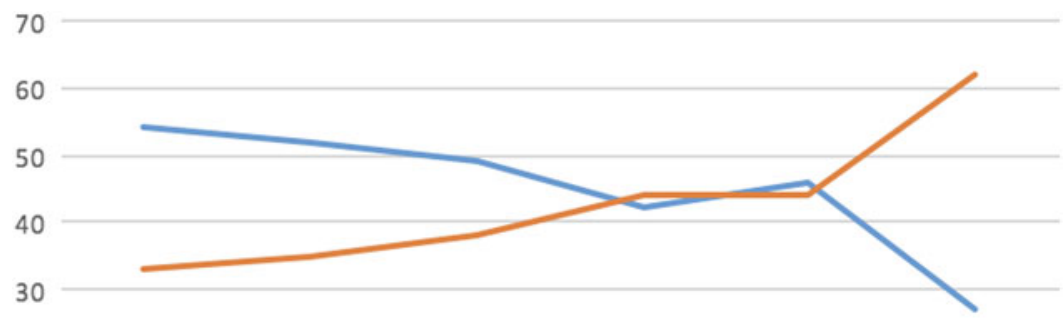

20

10

0

$\begin{array}{llllll}2010 & 2011 & 2012 & 2013 & 2014 & 2015\end{array}$

Figure 3. Changes in Kurdish votes for the AKP and the HDP (2010-2015) Source: Authors' own calculations based on data from KONDA

Class-based inclusion: Anti-elitism, populism, and welfare

In neighborhoods of İstanbul where a significant proportion of Kurdish migrants reside and work as daily wage laborers, the AKP's policies of resource distribution enabled the ruling party to maintain a strong relation with the Kurds. Serdar ${ }^{34}$ is a local of the city's Kağithane district, having worked there for the last 22 years. In his early forties, Serdar has worked in many different sectors, including construction and service. He came to İstanbul from the predominantly Kurdish province of Siirt in eastern Turkey during the forced migration of the 1990s. Throughout the 1990s, the war had created a sudden passage to urban life for millions of Kurds, as the Turkish state, pursuing a policy of counterinsurgency, evacuated around 4,000 villages and displaced more than two million rural Kurds. Today, the Kurds make up approximately 17 percent of contemporary İstanbul's total population, corresponding to almost three million people. ${ }^{35}$ This number makes İstanbul "the world's largest Kurdish city," as the saying goes among Kurdish migrants. Forced migration compelled Kurdish peasants to engage in a new mode of production as free wage-laborers and as a source of cheap labor.

As a result of his experience of state violence, Serdar became involved in politics and has supported legal pro-Kurdish parties since the 1990s. In an interview conducted in December 2013, Serdar explained why legal proKurdish parties had failed in metropolitan areas:

34 In conformity with classic anthropological tradition, all of the names of our interlocutors/informants have been changed.

35 KONDA, Kürt Meselesi'nde Algı ve Beklentiler (İstanbul: İletişim, 2011). 
Our parties [i.e., Kurdish parties] only talk about the mother tongue and language education. This is a valid form of propaganda in Kurdistan [i.e., southeast and east Anatolia]. In İstanbul, you can still talk about it, but nobody will listen to you unless you start talking about bread and butter.

This political failure-which, according to our ethnographic research, found expression in Kurdish workers' political discourses - opened up a space for the AKP to successfully mobilize the support of urban Kurds by recognizing their class identities. Until the June 2015 elections, Kurdish political parties had received only up to one-quarter of Kurdish votes in İstanbul, with the rest of the Kurds voting almost exclusively for the AKP. ${ }^{36}$ While Serdar and most of the Kurdish workers interviewed during our fieldwork support the Kurdish movement's struggle for the recognition of Kurdish identity and language, their precarious class position opens them up to populist policies, social assistance programs, and anti-elitist rhetoric, which in turn enables the class-based inclusion policy of the AKP.

The war in the 1990s, the concomitant forced migration of the Kurds, and economic restructuring led to the creation of an informal Kurdish workingclass population in the cities of western Turkey. ${ }^{37}$ This process has imbued the contemporary Kurdish identity with a class dimension: being Kurdish structurally denotes a particular class position in a Turkish urban setting. The AKP government cultivated successful relationships with the Kurds through the promise of an all-inclusive political platform for this ethnically and economically marginalized group.

Operating along the lines of an alternative, class-based Islamist populism, Islamists have shaped the class identities of the urban poor, especially the Kurds, into a contest over identities of a non-economic sort, including the politicized binaries of secularist-Islamist, urban-rural, and center-periphery. ${ }^{38}$ In its political competition with other political parties, the AKP endeavored to politicize the class divide by claiming that it represented the lower classes while the secular political opposition represented the economic and political elites.

36 However, for a number of reasons, including the strong organizational power of the Kurdish movement in the region and people's more direct exposure to state violence, the pro-Kurdish party received the support of almost half of the Kurdish voters in the Kurdish region as early as the 2011 elections; see Mesut Yeğen, "The 2011 Elections and the Kurdish Questions," Insight Turkey 13, no. 4 (2011): 147-169.

37 Onur Günay, "Becoming Kurdish: Migration, Urban Labor, and Political Violence in Turkey" (PhD dissertation, Princeton University, 2017); Erdem Yörük, "Welfare Provision as Political Containment: The Politics of Social Assistance and the Kurdish Conflict in Turkey," Politics \& Society 40, no. 4 (2012): 517-547.

38 White, Islamist Mobilization in Turkey; Tuğal, Passive Revolution. 
Coming from a working-class neighborhood himself, the AKP's leader, Recep Tayyip Erdoğan, had at hand the ideological instruments, images, and discourses to enable him to continuously perpetuate his rhetoric of being "a man of the people." The well-known motto of the AKP, milli irade ("the will of the nation"), refers implicitly to the Muslim lower classes as opposed to the secularist economic and political elite. ${ }^{39}$ The AKP has thus strategically deployed class differences to create a sense of commonality among its heterogeneous constituency.

During the period of economic growth that led to Turkey's labeling as an emerging market - a growth that was sustained with the help of liquidity flows from global financial markets-employment opportunities flourished, which rendered ethnic hierarchies much less visible in the labor market. Our ethnographic evidence shows that, up until the economic slowdown, Kurdish workers believed that work and wealth were equally available to Kurds and Turks. Seeking out networks of solidarity and patronage, Kurdish migrant workers filled the ranks of Islamic communities and Sufi orders, and indeed, many of our interlocutors mentioned that the members of such communities and orders were often able to find jobs through such groups. These groups function as "non-party affiliates" through which the AKP outsources the distribution of material benefits for appealing to poor voters. The governing Bharatiya Janata Party (BJP) of India, as shown by Tariq Thachil, uses a similar strategy: elaborating on poor voters' support for elite parties, he argues that elite parties linked to religious social movements outsource the task of mobilizing poor voters to their non-electoral organizational affiliates. ${ }^{40}$ This enables them to sustain their core elite constituency while simultaneously recruiting broad masses of poor voters.

The fact that the Kurds in İstanbul are predominantly working class and poor makes them more open to populism and generates an ever-expanding competition between the AKP and Kurdish parties over the Kurdish electoral constituency. Analysis of electoral polls shows that the AKP and the pro-Kurdish HDP are largely supported by the lower classes, while the main opposition Republican People's Party (Cumburiyet Halk Partisi, CHP) depends on middle- and upper-class constituencies. Both AKP and HDP votes are negatively correlated with income and education, while the CHP represents the opposite trend. ${ }^{41}$ As such, the AKP has politically instrumentalized welfare

39 S. Erdem Aytaç and Ziya Öniş, "Varieties of Populism in a Changing Global Context: The Divergent Paths of Erdoğan and Kirchnerismo," Comparative Politics 47, no. 1 (2014): 41-59.

40 Tariq Thachil, "Elite Parties and Poor Voters: Theory and Evidence from India," American Political Science Review 108, no. 2 (2014): 454-477.

41 KONDA, "7 Haziran Sandık ve Seçmen Analizi)"; SAMER, "Seçmenlerin Toplumsal Profili ve Siyasal Eğilimleri Sınıf, Toplumsal Cinsiyet, Etnisite, Din, İdeoloji ve Gezi Olayları," 2014, https://docplayer. 
provisions in its efforts to co-opt the Kurdish unrest and gain the support of the Kurdish poor. ${ }^{42}$ Previous quantitative research supports this argument, showing that Kurds are twice as likely to benefit from the country's free health care program, after controlling for eligibility-related factors. ${ }^{43}$ The AKP government has channeled rapidly expanding social assistance programs to Kurds in the Kurdish region as well as in Turkish metropolitan areas in a rather clandestine way: although the programs officially do not operate on an ethnic basis, they are disproportionately directed to Kurds via geographical budget allocations and political discretion at the local level.

Ethnic inclusion: Muslim brotherhood, critique of the secular state, and the peace process

The AKP differentiated itself from previous right-wing governments in Turkey by providing freedom for Islamic orders and communities in which ethnic inclusion could take place. According to the teachings of religious leaders and the discourses of Kurdish workers, the freedom to organize under the banner of Islamic orders is considered a sign of the emancipatory potential presented by the country's Islamist government. The central government and AKP municipalities support these Islamic groups both morally and financially. As important institutional bases of Islamic solidarity, the religious communities became dominant actors in the organization of religion as well as in building support for the government. This Islamic solidarity model, in turn, was "portraying itself as the only viable option for a peaceful resolution to ethnic conflict." 44 An inclusive project of living together and a resolution to the Kurdish conflict were offered up via the notion of "Muslim brotherhood" and the integration of Sunni components within the Kurdish population-a process that occurred at the expense of the Alevi and secular Kurds and non-Muslims.

Our anthropological research in İstanbul showed that Islamist orders and religious communities constituted the main grassroots institutional base for garnering Kurdish support for the Islamist movement through the cultivation of moral Islamic subjectivities and communities. In the diverse metropolises of western Turkey, the Islamic solidarity project claimed to lay the groundwork

biz.tr/7160826-Secmenlerin-toplumsal-profili-ve-siyasal-egilimleri-sinif-toplumsal-cinsiyet-etnisitedin-ideoloji-ve-gezi-olaylari.html.

42 Erdem Yörük, "Welfare Provision as Political Containment: The Politics of Social Assistance and the Kurdish Conflict in Turkey," Politics \& Society 40, no. 4 (2012): 517-547.

43 Erdem Yörük and Hişyar Özsoy, "Shifting Forms of Turkish State Paternalism Toward the Kurds: Social Assistance as 'Benevolent' Control," Dialectical Anthropology 37, no. 1 (2013): 153-158.

44 Ayşen Candaş and Ayşe Buğra, "Solidarity among Strangers: A Problem of Coexistence in Turkey," Constellations 17, no. 2 (2010): 293-311. 
for relations between Turks and Kurds in everyday life. Islamic solidarity offered a language of coexistence and an intercommunal form of law that would regulate everyday interactions and conflicts. Interethnic conflicts between Kurdish and Turkish youth were de-ethnicized under the banner of the unity and solidarity of the Islamic ummab.

Unlike the Turkish governments of the 1990s, which had intensified the war with the PKK, the AKP was more pragmatic and risk-averse in its position on the Kurdish conflict. In order to resolve the Kurdish issue, the AKP launched successive waves of reconciliation projects under different names, including the "democratic initiative" (demokratik açılım), "national unity and solidarity" (millî birlik ve beraberlik), "the Oslo process," and "the Peace Process" (barış or çözüm süreci). For metropolitan Kurds, the expansion of Kurdish rights was a byproduct of the AKP's political choices, which enabled the translation of the Kurdish struggle into the language and rubric of cultural and political rights. As the questions of a pro-AKP Kurdish worker about the peace process put it succinctly in an interview conducted during our fieldwork: "Before the AKP, don't you think that the Kurdish movement was struggling? Don't you think that the guerrillas were strong before this government?" Up until late 2014, this was still a common feeling among Sunni Kurds in İstanbul.

Moreover, there was fear among the urban Kurdish community that popular support of pro-Kurdish parties would increase ethnic tensions, making the Kurds more vulnerable to Turkish nationalist attacks in working-class neighborhoods of the major cities. Kurdish İstanbul is full of narratives of violence portraying police brutality and torture as well as collective violence and discrimination enacted against Kurdish migrants during the 1990s. ${ }^{45}$ This fear significantly shaped the electoral trends of the older generations among Kurds.

For the Kurds of İstanbul, Turkish secular and nationalist parties came to represent a return to the notorious 1990s, which as mentioned was an era of state violence and ethnic discrimination against the Kurds. Workplace and coffeehouse conversations among Kurdish workers always include politics. After the death of Berkin Elvan in $2014,{ }^{46}$ some supporters of the Kurdish movement and the AKP alike criticized the HDP's participation in the Gezi protests against the government. For instance, Ali, a young Kurdish

45 Onur Günay, "In War and Peace: Shifting Narratives of Violence in Kurdish Istanbul," American Anthropologist 121, no. 3 (2019): 554-567.

46 Berkin Elvan was a 15-year-old Turkish boy hit on the head by a tear-gas canister fired by a police officer in İstanbul while out buying bread for his family during the June 2013 Gezi protests. He died on March 11, 2014, following a 269-day coma, and widespread demonstrations erupted after his death. 
worker from Iğdır, was highly suspicious of the Gezi protests and of Kurdish involvement in them:

Look, for God's sake, I've never supported Tayyip Erdoğan in my life. Yet if these [Gezi] protests ended up overthrowing him and brought the [far-right nationalist] MHP and the [secular nationalist] CHP to government, would the country be in a better position? Doesn't our party [i.e., the HDP] remember the 1990s? Aren't they [i.e., Turkish nationalist parties] our murderers? This is the first time someone [i.e., Erdoğan] takes you seriously, openly and officially negotiates with your leader [i.e., Abdullah Öcalan]. And do you want to overthrow him and bring in the murderers and gunmen of the 1990s?

As he said this, an elderly pro-AKP Kurdish man sitting at the next table responded to him immediately in Kurdish, "Erdoğan bavê Kurdan e" ("Erdoğan is the father of the Kurds"). Although Ali and other HDP supporters rejected this idea, they used to think that, in terms of ethnic politics, the Islamist Erdoğan actually did much more than Turkish nationalist parties and their leaders. In their electoral propaganda for the Kurds, the AKP criticized the oppressive state tradition of the secularists. The AKP's recognition of the state's past massacres and disasters-even if only in limited, hesitant, and highly convoluted forms ${ }^{47}$ - produced and sustained an image of a government that differed from previous governments in terms of ethnic politics. The AKP's selective critique of state violence fortified the promise of peace among the Kurds and provided further legitimacy for the government party; after all, the Islamists claimed to be victims of the same secular state tradition that oppressed the Kurds. ${ }^{48}$

In other words, the Islamists' electoral success among the Kurds depended on the belief that the AKP government was uniquely willing to solve the Kurdish question in Turkey, albeit slowly. Various forms of this political discourse were repeated among Kurdish migrant workers, in both ethnographic encounters and interviews. There was a strong belief among the Kurds that the AKP had granted them linguistic and cultural rights, including the freedom to speak Kurdish in public, alongside Kurdish-language broadcast state television, language schools, and elective Kurdish courses. Not surprisingly, AKP activists in the field promoted this idea vehemently, especially during elections. This promise and its partial realization through the granting of

47 Bilgin Ayata and Serra Hakyemez, "The AKP's Engagement with Turkey's Past Crimes: An Analysis of PM Erdoğan's 'Dersim Apology'," Dialectical Anthropology 37, no. 1 (2013): 131-143.

48 Onur Günay, "Toward a Critique of Non-Violence," Dialectical Anthropology 37, no. 1 (2013): 171-182. 
certain cultural rights (but not collective political rights) effectively drove metropolitan Kurds to the AKP.

In summary, the AKP's reliance on a Sunni-based Islamic solidarity allowed the government party to distinguish itself from the Turkish nationalist tradition by promising ethnic inclusion into the Islamic ummab. Our analysis shows that the Kurds in İstanbul did not support the AKP simply as a result of their religiosity, religious sectarian differences, or conservative ideology ${ }^{49}$ On the contrary, metropolitan Kurds felt that they could comfortably live with their ethnic and linguistic differences under the umbrella of Islamic solidarity -a feeling unquestionably reinforced by the peace process between the government and the Kurdish movement and the relative absence of political violence-even while their class position was being strengthened via the AKP's material networks.

\section{Why did the Kurds stop supporting the AKP?}

The general elections held on June 7, 2015 threatened the long-standing AKP rule, a shift that was for the most part caused by a dramatic increase in votes going to the pro-Kurdish party. While the HDP gained 3.2 million votes in the Kurdish region-as compared to the 2.3 million votes cast for the previous Kurdish party, the Peace and Democracy Party (Barıs ve Demokrasi Partisi, $\mathrm{BDP}$ ) in the 2011 elections - the most unexpected rise in votes came from the metropolises of western Turkey: from the 2011 to the June 2015 elections, votes for the pro-Kurdish party increased from 530,000 to 2.8 million. In İstanbul, where 18.5 percent of the country's valid votes were cast, the pro-Kurdish party increased their votes from 0.4 million (6.58 percent) to 1 million (12.14 percent). A more detailed look at the June 2015 election results indicates that the AKP government lost votes especially in the poor metropolitan neighborhoods of the western metropolises and in the Kurdish region, where it used to obtain around half of the votes or even more. ${ }^{50}$

The most significant reason why the AKP lost Kurdish support was the AKP's stance during the 2014 battle of Kobanê. After the Islamic State

49 In this sense, our analysis stands in stark contrast to Zeki Sarıgil and Ömer Fazlıoğlu, "Exploring the Roots and Dynamics of Kurdish Ethno-nationalism in Turkey," Nations and Nationalism 20, no. 3 (2014), 436-458 and Faruk Ekmekçi, "Understanding Kurdish Ethnonationalism in Turkey: Socioeconomy, Religion, and Politics," Ethnic and Racial Studies 34, no. 9 (2011): 1608-1617.

50 It is important to note that, while the AKP's share in national votes (and in İstanbul as well) increased between the 2007 and 2011 elections, its share in the Kurdish region decreased over the same period; see Yeğen, "The 2011 Elections." For data on the 2015 elections, see IPSOS, "2015 Genel Seçim Sandık Sonrası Araştırması"; KONDA, "1 Kasım Sandık ve Seçmen Analizi Raporu"; KONDA, "7 Haziran Sandık ve Seçmen Analizi"; Meyersson, "How Turkey's Social Conservatives Won the Day for HDP"; Öz, "Vote Transitions in Turkish General Elections." 


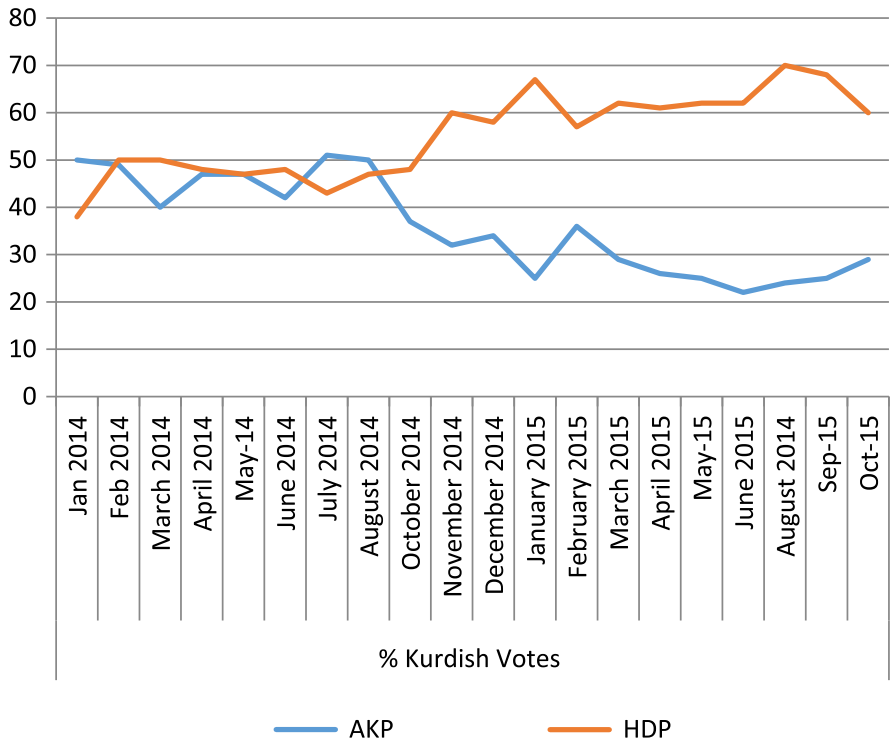

Figure 4. Changes in Kurdish votes for the AKP and the HDP (January 2014-October 2015)

Source: KONDA, "7 Haziran Sandık ve Seçmen Analizi"

(IS) had attacked Kobanê, a Kurdish city in northern Syria/western Kurdistan (Rojava), Kurdish votes radically swung from the AKP to the HDP. The survey data suggests that the Kurdish vote rate for the AKP declined from one-half to one-fifth during the eight months following the battle, as shown in Figure 4, where Kurdish votes are analyzed in more detail.

The AKP government's perceived support for jihadist organizations, and specifically IS, during the Syrian Civil War, together with resistance by Kurdish fighters in Kobanê and the defeat of IS in Rojava, significantly diminished Kurdish support for the AKP in Turkey. The battle of Kobanê turned out to be "a war of existence for the Kurds" in Syria, as many Kurds call it. A significant proportion of the Kurds fighting against IS in northern Syria came from the Kurdish region in Turkey, and the bodies of hundreds of dead fighters were sent back to Turkey for funerals. These funerals turned into affective spaces that not only intensified resentment against the Turkish state and the AKP government, but also radicalized Kurdish nationalism across the borders of nation-states. Growing ethnic rage and trans-border nationalism among the Kurds in Kurdish areas, enabled by the struggle of the Kurdish forces in the Syrian Civil War, were transmitted to metropolitan areas via the movement of temporary migrant workers. The battle of Kobanê thus enabled the 
establishment of a powerful and radical Kurdish nationalism that transcended nation-state borders.

Kurds came to think that the Turkish nationalism implicit within Islamic solidarity had become much more visible during the battle of Kobanê, undermining the very idea of equality among the Muslim members of Islamic communities. As we observed during our fieldwork, the participation of Kurdish members in Sufi orders and religious communities had fallen drastically during the harshest moments of the Kobanê conflict. For Kurds, non-participation in religious rituals and gatherings became a fundamental mode of disobedience and opposition to religious authorities. The Kurdish grievance, in turn, became a basis for splits and tension within the Islamic community as well. As observed in our research, when one Kurdish member of the Islamic community voiced a critique of IS's attacks on the Kurds, it was dismissed by the mullah of the community as a sign of Kurdish racism ( $r$ rkçılı), with the mullah angrily shouting at the young boy who voiced the critique, "Don't be a racist!" After the battle of Kobanê, Kurds came to believe that Turkish national supremacy was being reproduced under the guise of Muslim/Islamist brotherhood. As our Kurdish interlocutors reiterated, a significant proportion of the Islamic communities and Sufi orders did not criticize IS' policies or its attacks on the Syrian Kurds. This led pious Kurds to question the Islamic solidarity being offered by the AKP government as a political model and a solution to the Kurdish issue.

Kurdish perception of their position in Turkey was also transformed by the lynching of Kurds that occurred during the Kobanê-related riots in October 2014. On October 9, a Kurdish construction worker was lynched in İstanbul's Esenyurt district, being undressed, beaten, and stabbed 15 times. His story circulated widely at Kurdish coffeehouses and workplaces among Kurdish workers, who identified with his ethnic and class background. The belief that the AKP would give Kurds their rights and make them equal citizens with Turks was losing its hold on metropolitan Kurds.

That belief was finally critically undermined in March 2015, three months before the general elections, when President Recep Tayyip Erdoğan called for an end to the peace negotiations between the PKK and the Turkish state. $\mathrm{He}$ even refused to acknowledge the existence of the Kurdish problem, which echoed the violent period that country had seen in the 1990s. This "unexpected move" seriously harmed Kurdish hopes for an AKP-led peace. During the subsequent electoral campaign, HDP volunteers and politicians were subjected to violent attacks: the HDP headquarters in Adana and Mersin were bombed, a party member was executed in Bingöl, there was an organized lynching effort in Erzurum, and at the biggest HDP rally in Diyarbakır - the symbolic capital of the Kurds-bomb blasts killed four people and injured more than two 
hundred. Such massacres, executions, murders, and lynches created a fear of "a return to the violent 1990s" among the Kurds. The AKP government, which had received such significant support from the Kurds with its promise to solve the Kurdish issue and its critique of the Turkish state and the conflicts of the 1990s, seemed to have lost much of its credibility for Kurds in an unexpectedly short period of time.

In poor working-class districts of İstanbul like Bağcllar, Sultanbeyli, Ümraniye, Kağıthane, Esenler, and Sultangazi, where the AKP had received between 50 and 70 percent of the votes in 2011, the numbers and percentage of AKP votes declined precipitously. Statistical analysis demonstrates that, in these neighborhoods, the HDP took a large number of votes from the AKP in June 2015..$^{51}$ This is where temporary migrant workers from the Kurdish region played a decisive role in the elections, as these workers became the driving force of the electoral campaign and carried the political radicalism of the Kurdish region and Rojava into the heart of Turkish metropolises. Their energy during the door-to-door electoral campaign influenced previous generations of Kurdish migrants as well. One ethnographic vignette from our field notes speaks to this political interaction among different generations:

It is almost midnight. There is no traffic on the street. Most of the Kurdish migrant workers who worked during the day and evening are back. They are banging HDP flags on the buildings next to the street. One woman from a nearby building is yelling at them: "You cannot hang terrorist flags on my building." She is yelling as loud as she can in the silence of the night. While the migrant workers remain silent because they are advised not to respond to any provocation, an elderly Kurdish man in his seventies, who just happens to be there at the time, responds to the woman immediately: "Aren't you ashamed of yourself? You call me "uncle" [a term of respect].This is our flag, you have to learn how to live with that." Young Kurdish workers are confused. They later told me that, like most of the older immigrants, the old Kurdish man used to be a supporter of the Islamist AKP government. They keep banging the flags.

The dissolution of the class-based inclusion of the Kurds proved to be critical for explaining the erosion of Kurdish support for the AKP. During Turkey's economic slowdown, economic resources and employment opportunities in religious communities and the party cadres have been unequally distributed among Kurds and Turks. This has led to disappointment with the

51 KONDA, "7 Haziran Sandık ve Seçmen Analizi"; Öz, "Vote Transitions in Turkish General Elections." 
Islamic solidarity project among pious Kurds. The following encounter, which occurred between a Kurdish and a Turkish worker, provides an ethnographic account of the revitalization of ethnic hierarchies in the labor market during the economic slowdown, which was another important force lying behind the Kurdish swing votes.

Kerem is a pious Kurdish worker in his late twenties. He has worked in many different sectors over the last 15 years. Like many other workers in the informal sector, he has no job security, and in the summer of 2014 he was fired from his job at a supermarket. He became utterly depressed and worried about his future. While we walked through the neighborhood, he talked about his plans to get married, and about life in general. He said that he needed to save money for marriage but could not find a stable job that would allow him to do so. Then we ran into Ahmet, who is from the same religious community. In his early forties, he is a Turkish bazaar worker from Giresun. From Ahmet we learned that the AKP-led municipality had hired him and his brother. $\mathrm{He}$ was happy about his new job and the social security it provided. He said that they had found their jobs through their connections in their Sufi order. Afterward, Kerem's sister came and we walked toward their home.

Although he was initially silent, Kerem eventually said: "If you ask them, we're all Muslims. Whenever there's a job or economic opportunity, our Turkish fellows get it. I don't really understand!" Like Kerem, his Kurdish friends and other young people were experiencing tremendous difficulties in finding jobs. Indeed, the drastic decrease in the economic growth rate, down from 10.3 to 2.1 percent between 2011 and 2015, reinvigorated ethnic hierarchies in the labor market and the distribution of economic resources. "A shrinking economic pie" thus revitalized ethnic hierarchies that had been covered under the umbrella of Islamic solidarity during the period of economic growth. Many Kurds felt discriminated against and excluded from employment distribution, which led them to once more question the sincerity of Islamic solidarity and the AKP's reconciliatory gestures, and consequently to shift their electoral choice. Such questions as these were coupled with resentment toward the absence of the Kurds in high positions of the AKP's party organization at both the local and the national level. The unequal distribution of economic and political resources was thus a significant reason behind the recent failure of the Islamic solidarity project among the Kurds. But of course, there is another side to the story as well.

In 2012, the Kurdish political movement allied with a wide array of socialist, feminist, environmentalist, and LGBTQ organizations, as well as with representatives from religious and ethnic minorities, to establish the HDP. This alliance with other communities and oppositional currents in the country provided the Kurdish political movement with broader legitimacy and a 
greater capacity to articulate the Kurdish question within the framework of the larger problem of democratization in Turkey. Thus, as a broader coalition of Kurds and other oppositional groups, the HDP managed to attract much wider support from Kurdish and non-Kurdish groups, to a degree unprecedented by previous pro-Kurdish legal parties. In the Kurdish region and the metropolises of western Turkey, the HDP emerged as the AKP's main political rival in working-class neighborhoods, especially during the peace process. The decreasing level of political violence during this process opened up a legitimate space for Kurds and other marginalized groups to voice their political demands for cultural and political rights. Although pro-Kurdish parties had been entering into electoral politics since the early 1990s, up until 2015 their share of votes in the country had remained within the 4-6 percent range. In 2015, though, the HDP gained 13.12 percent of the countrywide vote, and it also became the first pro-Kurdish party in Turkish history to garner the majority of Kurdish votes.

The political unease with the government party among Kurds did not, however, mechanically translate into HDP electoral success. The HDP's emphasis on radical democracy and egalitarian forms of living together-an emphasis much more inclusive than what is seen in Turkish nationalism and Islamic solidarity - proved a critical factor in changing the voting behavior of metropolitan Kurds. Those who had been included within the circles of Islamic solidarity (i.e., the poor and Kurds) but regarded as less equal members thereof now turned to embrace the new ways and alternatives of living together proposed by the HDP. In this context, we argue that the HDP's model of "radical democracy" 52 found its most powerful response among the Kurdish urban working classes. This model received significant support from metropolitan Kurds, who had begun living as second-class citizens in diverse urban spaces and/or "second-class Muslims" in Islamic communities.

The fact that so many different segments of society were represented among the HDP's electoral candidates-among them Armenians, Turks, Kurds, Muslims, non-Muslims, feminists, LGBTQs, leftists, and Islamists - reinforced the HDP's call for a new model of living together. Progressive intellectuals and certain segments of the Turkish middle classes who had joined the 2013 Gezi protests also welcomed the HDP's project of radical democracy. The peace process and the Gezi protests thereby contributed further to the legitimacy of the HDP's radical demands for the Turkish public, which in turn made it easier for metropolitan Kurds to support the party.

52 For a detailed discussion of the Kurdish political movement and the concept of radical democracy, see Ahmet Hamdi Akkaya and Joost Jongerden, "Reassembling the Political: The PKK and the Project of Radical Democracy," European Journal of Turkish Studies: Social Sciences on Contemporary Turkey 14 (2012), https://journals.openedition.org/ejts/4615. 
As was mentioned above, metropolitan Kurds were afraid of being criminalized and marginalized as a result of possible identification with pro-Kurdish parties, an identification that was seen by the general public as an act of "terror." The HDP's alternative project thus created strong pull conditions for the Kurdish constituency that departed from the AKP.

\section{How did the AKP replace Kurdish votes with Turkish nationalist votes?}

Having been weakened in the June 2015 elections, the AKP subsequently developed a new mode of ethnic politics whereby the authoritarian repression leveled against the Kurdish opposition became the central strategy of garnering Turkish nationalist support. Following the AKP's electoral setback in June and the failed attempts to form a coalition government, Erdoğan called for snap elections that were set to take place in November 2015. These elections would be held after the resurgence of war between Kurdish insurgents and the Turkish armed forces and an extended period of political turmoil. The AKP votes, which had declined to 40.9 percent in the June 2015 elections, increased to 49.5 percent with the shift of Turkish nationalist votes, following an authoritarian counterinsurgency that included an anti-PKK military campaign, strong use of anti-terror rhetoric, and repression of the opposition.

During the November elections, the massive support secured by the AKP from Turkish nationalists resulted largely from the AKP's anti-PKK campaign, which was seen by the Turkish nationalist electorate as a sign of the AKP's capacity to restore political stability and to govern the ethnic conflict through authoritarian repression, war, and violence. The vast majority of the new AKP votes, which brought a landslide victory for the party, were from Turkish nationalist voters who in June had either not voted or had voted for other Turkish nationalist and conservative parties. In the November elections, according to calculations by KONDA and Erik Meyersson, a large majority (87 percent) of the new votes for the AKP came mainly from three sources:

(1) The Nationalist Movement Party (Milliyetçi Hareket Partisi, MHP), with 10 percent of MHP votes passing to the AKP in November;

(2) Turkish nationalist and Islamist votes from mainly the Felicity Party (Saadet Partisi, SP) and the Great Unity Party (Büyük Birlik Partisi, BBP, with 61 percent of those voting for such small parties in the June elections shifting to the AKP in November;

(3) AKP voters who had not voted in the June elections, with 71 percent of those who had not voted in June voting for the AKP in November. ${ }^{53}$

53 KONDA, "1 Kasım Sandık ve Seçmen Analizi Raporu)"; Meyersson, "Kinky Voting." 
This new support for the AKP continued after the November elections as well. As a result, the percentage of ethnic Turkish votes among total AKP votes increased from 81 percent to 90 percent during the year after the June 2015 elections, based on the authors' calculations of KONDA data. That is to say, the AKP constituency lost much of its ethnic heterogeneity over this period, as according to KONDA the number of Kurdish swing votes that shifted from the HDP to the AKP between June and November was very small. What is more, many Kurds who would have voted for the HDP either chose not to go to the ballot box in November or could not go due to conflict. ${ }^{54}$

How did this transformation occur? The periods between the June and November elections in 2015 and after the November elections witnessed an escalation of political violence and terror to unprecedented levels. In this ethnic turmoil, 925 people, mostly PKK members but also 169 civilians, were killed, and around 3,600 people were detained in security operations just in the time between the June and November elections. ${ }^{55}$ Armed conflict between the Turkish army and the PKK began in July 2015, one month after the elections, following the Suruç massacre of July 20, when a suicide bomber associated with IS killed 34 left-wing and Kurdish university students (mostly HDP members) and injured over 100 in Suruç, a Kurdish town on the Turkish border with Syria. The Suruç massacre was followed by the Ankara massacre organized by IS on October 10, which killed 102 left-wing and Kurdish activists and injured hundreds. These massacres triggered the escalation of the armed conflict between the PKK and the state, and the public discourse rapidly became dominated by anti-terrorism campaigns: "International observers of the November elections are at a consensus that the campaign period was surrounded by 'a climate of violence and fear' [...] More than any other election in the post-1980 period, the November campaign was marred by violence, polarization, and inter-ethnic conflict. ${ }^{56}$

Nationalist mobilization was manifested not only at the ballot box, but also in escalating mob violence against the Kurds and the HDP on the streets. From June 2015 on, there were over a hundred attacks on HDP buildings and branches, a trend that accelerated after the November elections and especially after the failed coup attempt of July 15, 2016. The long summer of 2015 now seems like only a prelude to the waves of repression that mounted

54 KONDA, "7 Haziran Sandık ve Seçmen Analizi," 42.

55 Irfan Aktan, "Bloodshed Stokes Kurdish Separatist Sentiment," Al-Monitor, December 9, 2015, http:// www.al-monitor.com/pulse/originals/2015/12/turkey-kurds-bloodshed-stokes-separatist-sentiment. html.

56 Berk Esen and Şebnem Gümüş̧̧ü, "Rising Competitive Authoritarianism in Turkey," Third World Quarterly 37, no. 9 (2016), 1595. 
gradually and peaked after July 2016. Following the failed coup attempt, the AKP launched a crackdown on political opposition that went far beyond the members of Fethullah Gülen's community, who were held responsible for the attempt. The co-chairs of HDP, Selahattin Demirtaş and Figen Yüksekdağ, along with eight other HDP deputies and several HDP mayors, were imprisoned in the autumn of 2016. In the meantime, 34 municipalities governed by the HDP were put under the control of government-appointed officers instead. Hundreds of left-wing and Kurdish NGOs were closed. Placed under curfew, Kurdish cities were destroyed and made uninhabitable by the military crackdown imposed by the state. A recent report by the Office of the United Nations High Commissioner for Human Rights indicates that between July 2015 and December 2016 more than 2,000 people were killed in the context of security operations in southeast Turkey (i.e., the Kurdish region), while a series of laws adopted on June 23, 2016 created an atmosphere of "systematic impunity" for Turkish security forces. ${ }^{57}$

We conducted focus group interviews to understand how the AKP swing voters understood, experienced, and interpreted the resurgence of war and the anti-terror campaigns. The interviews were conducted with informants who (i) are of Turkish ethnic origin, (ii) did not vote for the AKP in the June 2015 elections, (iii) voted for the AKP in the November elections, and (iv) still support the AKP. The informants were between 25 and 50 years of age, and half of them were women. We worked with a research company specializing in qualitative research, Binom, ${ }^{58}$ which selected the sample from its large pool of informants. Conducted in December 2016, these interviews provided us with useful data on how and why new Turkish votes had come to the AKP between June and November 2015.

During the focus group interviews, we asked informants about their motivations to vote in both of the elections of 2015, and more importantly, how and why their motivations had changed. As regards their vote change from June to November 2015, among a multiplicity of political and economic reasons, the resurgence of war between the Turkish state and the PKK appeared as the most salient factor, followed successively by the war in Syria; economic problems (poverty, unemployment, and inequality); the European Union; and Fethullah Gülen. Two themes dominated the focus group discussions about vote preferences; namely, the will to end chaos and terror and the reaction against the peace process and the rise of the HDP.

57 Office of the United Nations Commissioner for Human Rights (OHCHR), "Report on the Human Rights Situation in South-East Turkey: July 2015 to December 2016," February 2017, https://www.ohchr.org/ Documents/Countries/TR/OHCHR_South-East_TurkeyReport_10March2017.pdf.

See http://www.binomarastirma.com/en/. 
The will to end chaos and terror

For all participants, the period between the June and November elections was characterized by political chaos and violence. One informant, Hatice-a retired technician in her mid-fifties whose husband is a civil servant — characterized this period as chaotic: "It was full of uncertainties and question marks. Neither of the parties was able to resolve it. Then economic and political chaos followed. It was totally chaotic. Turkey was at loose ends." Fatma, another lower middle-class participant who is a graduate in the field of public administration, supported her views as follows: "The leadership of Recep Tayyip Erdoğan was appealing to me. If I had voted for another party, this party would not have showed a governing style as stable as that of Erdoğan. I thought that other parties could not resolve the terror problem. The AKP did show stability for coping with terror. The AKP slammed an iron fist down on the table. Only the AKP could do this."

Following Fatma's statement, we asked other informants whether they supported the AKP because the government had used an "iron fist" against the Kurdish movement. The answer was a unanimous yes. Ahmet, a private security guard who had voted for the MHP in June, said: "The AKP shouldered responsibility for countering terror. Others would have sidestepped." Hakan, a 38-year-old skilled worker and Turkish nationalist, agreed with him, arguing that "it was important that the AKP arrested the HDP members one by one. Other parties only do opposition, but the AKP is much more astute; it was able to say 'no' to terror." All except one informant said that only the AKP government would have been able to effectively end terror. We then asked whether, in their opinoin, an "iron fist" or a peace process would work better to end terror. All except one informant preferred the "iron fist." Mustafa was even more radical, stating: "All of those involved in terror should be executed."

The reaction against the peace process and the rise of the HDP

The peace process between the PKK and the Turkish state was disappointing for our conservative and nationalist Turkish informants. Most of them regarded the political and social changes that had occurred during the peace process as contradictory. As Hakan put it, they were confused as to "whether there was a peace deal or not" and "whether the government really negotiated with the PKK." In fact, all of them thought that the political power of the Kurdish movement had grown during the peace process. For Hatice, this was the reason that she turned to support the AKP in November: "Who started the peace process? The AKP. Who could finish it? The AKP. You must give every job to experts; you must let the cook make the food." 
For our Turkish nationalist respondents, the HDP's rise meant the increasing power of terror. Fatih explicitly said that "after the HDP's vote increased in the June elections, many people said, 'Oh dear, what did we do?!' In the November elections, I voted for the AKP so as not to divide the votes, as a reaction to the HDP." Hatice and Mustafa were also scared of the 13 percent vote received by the HDP. Hatice stated that she "did not want the HDP to grow anymore," while Nuriye said she had also "voted for the AKP in November to prevent the HDP from gaining more power." Hakan was also thinking along the same lines: "Even some AKP people voted for the HDP in June, because they found the HDP and its leader Demirtass sympathetic. What happened after the June elections? Chaos came in. We thought only the AKP could fix it. I believed the AKP would terminate the peace process." When we asked what they thought about the HDP deputies being put into prison, all of them said that this was a sound but late decision.

Based on these findings, we argue that the government's anti-terror campaign not only affected the Kurdish opposition, but also helped mobilize Turkish nationalist voters based on an engineered fear of prolonged instability and national disunity. The politics of fear and violence, along with accompanying concerns about economic and political instability, helped the AKP and Erdoğan restore their power. In addition to the unleashing of IS terror, turmoil, and threats of instability, the AKP also mobilized chauvinism in the west of Turkey through the escalation of war in the Kurdish region. To this end, the AKP deployed a "narrative of stability," arguing that the current political instability and Kurdish insurgency could only be fixed by bringing the AKP back to power. The nationalist and conservative Turks who had formerly supported other right-wing parties accepted this argument, and Turkish public resentment against Kurdish demands for self-rule and autonomy found its expression in the AKP's war on terror, which meant a brutal authoritarian counterinsurgency. This period, which coincided with the brutal war between Kurdish forces and IS in Northern Syria, created an authoritarian turn in Turkey. The cost of the Islamists' electoral success, though, was excessively high: the destruction of people's right to the freedom of speech, the suppression of relatively critical but effective mass media tools, and the initiation of a campaign of authoritarian counterinsurgency targeting the Kurds and political opposition. ${ }^{59}$

Although our focus in this article is on examining the ethnic politics of the Islamist AKP in order to explain its fluctuating hegemony, the shift of voters toward the AKP, just as much as their shift away from it, depends also on the

59 David H. Ucko, "The People are Revolting': An Anatomy of Authoritarian Counterinsurgency," Journal of Strategic Studies 39, no. 1 (2016): 29-61. 
agency of other competing political organizations, including the Kurdish movement. After the HDP gained unprecedented electoral success in the June 2015 general elections, the rapid and violent escalation of war helped the AKP gain back lost nationalist votes. Some of the Kurdish HDP supporters who sought integration and peace held both the state and the Kurdish movement responsible for the rapid escalation, which in the Kurdish region led to a sense of the futility of voting, low turnout in the elections, and consequently higher AKP voting rates. However, a full analysis of the situation in the Kurdish regions would require a much more detailed empirical study.

\section{Conclusions}

The growing scholarship on Islamists has failed to explain variations in support for Islamists. For instance, why do Islamists experience rapid declines or increases in electoral support in consecutive elections? In explaining such a multifaceted phenomenon as the success of Islamist movements, ethnic politics has proven to be a key component, yet remains largely unexplored in the current literature. Our aim in this article has not been to dismiss the sources of popular support for Islamists that are identified in the literature, but rather to contribute to the literature by bringing the ethnic politics of Islamist movements into conversation with the existing explanations, and thus to broaden our understanding of this complex phenomenon.

The political configurations of Islamists' diverse electoral performances depend on their capacity to govern ethnic conflicts. Our ethnographic and sociological analysis shows that fluctuating support for the AKP government in Turkey has been conditioned to a large extent by the way the party has dealt with the Kurdish question via different modes of ethnic politics, including changing configurations of repression and inclusion: (i) the Islamists grew in power when they presented a peaceful resolution to the Kurdish ethnic question through ethnic and class-based inclusion of Kurds within the broad Islamic solidarity project; (ii) the Islamists lost their Kurdish voters-and thus their broader hegemony-when they failed to realize the promise of equality between Kurds and Turks during the battle of Kobanê, as well as due to other factors, such as the economic slowdown and the end of the peace process; and (iii) the Islamists regained national power when they used anti-Kurdish repressive politics and growing authoritarianism to mobilize Turkish nationalist support in place of lost Kurdish votes. The AKP's ability to shift between these different logics of ethnic politics has laid the ground for its continuing political hegemony and growing authoritarianism. 
While establishing political hegemony before late 2014, the AKP government had promised the ethnic inclusion of Kurds through the idea of Islamic solidarity, refraining from making explicit overtures to Turkish nationalism. In line with this, they accelerated the peace process with the PKK, which brought a halt to the armed conflict and lessened the marginalizing effects of the conflict on metropolitan Kurds. Furthermore, the government also offered classbased inclusion of Kurds, who belong mostly to the urban working classes. During the period of economic growth, employment opportunities expanded, and many Kurds came to feel that ethnic hierarchies in the labor market had largely vanished under AKP rule. The AKP widened social assistance programs for the poor and favored Kurds in the distribution of these benefits. During this period, a significant proportion of the Kurdish constituency supported the AKP because they found a way to be included in society proper as Muslims, which in turn translated into being viewed as legitimate, equal, nonmarginal, non-terrorized, and non-criminal subjects. The Muslim brotherhood fostered under AKP networks legitimized their Kurdish identity while also rendering them acceptable.

In the general elections of June 2015, however, the Islamists lost the majority of Kurdish support, and hence their broader political hegemony. The AKP's perceived direct or indirect support for IS during the battle of Kobanê served as the primary trigger for the Kurds' departure from the $\mathrm{AKP}$ at a historical moment. Kurdish youth became radicalized by the struggle against IS during and after Kobanê, leading to the end of support for the AKP among a significant proportion of the urban Kurdish population. Furthermore, the end of the peace process created deep frustration among Kurds, and subsequently the AKP limited itself more and more to an exclusively Sunni Turkish nationalism at the expense of a more inclusive Islamic solidarity.

Additionally, the AKP's class-based inclusion project significantly weakened among the Kurdish poor. With the decline in economic growth, the government's capacity of welfare provision and resource distribution also declined. Simultaneously, there began to emerge a Turkish nationalist supremacy in terms of resource distribution. As the economic pie shrank, ethnic hierarchies reappeared. The Islamic solidarity model morphed into discrimination, and inclusion became exclusion as Kurds faced greater poverty combined with less ethnic equality in the labor market.

Having lost national support and a parliamentary majority in the June 2015 elections, the AKP resorted to a repressive strategy against the Kurds that helped to mobilize ethnic Turkish nationalists who had been alienated by the co-optation strategy of the previous period. The time between the June and November elections was characterized by ethnic violence, mobs, armed 
conflicts, and bombings, during the course of which the AKP promised Turkish nationalists that the party would repress the Kurdish movement and bring political stability. This strategy was an effective one, bringing AKP votes back to levels seen during the party's strongest period in 2011.

Last but not least, this article has pointed out that the way in which the ethnic issue shaped the electoral hegemony of the governing party in Turkey has also been conditioned by actions taken by the Kurdish opposition. While the first shift, which was characterized by the departure of Kurds away from the AKP and toward the HDP, was occasioned by the inclusive and radically democratic politics of the HDP, the second shift-i.e., the orientation of Turkish nationalist votes toward the AKP — was conditioned by the violent encounter between the PKK and the state in Turkey and Syria.

\section{References}

Ahmadzadeh, Hashem and Gareth Stansfield. "The Political, Cultural, and Military Re-Awakening of the Kurdish Nationalist Movement in Iran." The Middle East Journal 64, no. 1 (2010): 11-27.

Akkaya, Ahmet Hamdi and Joost Jongerden. "Reassembling the Political: The PKK and the Project of Radical Democracy," European Journal of Turkish Studies: Social Sciences on Contemporary Turkey 14 (2012). https://journals.openedition.org/ejts/4615.

Aktan, Irfan. "Bloodshed Stokes Kurdish Separatist Sentiment." Al-Monitor, December 9, 2015. http://www. al-monitor.com/pulse/originals/2015/12/turkey-kurds-bloodshed-stokes-separatist-sentiment.html.

Al-Ahsan, Abdullah. Ummah Or Nation?: Identity Crisis in Contemporary Muslim Society. Leicester: The Islamic Foundation, 1992.

Al-Azm, Sadik J. "Is Islam Secularizable?" Journal for the Critical Study of Religion 2 (1997): 83-90.

Amuzegar, Jahangir. "The Ahmadinejad Era: Preparing for the Apocalypse." Journal of International Affairs 60, no. 2 (2007): 35-53.

Anderson, Lisa. "Fulfilling Prophecies: State Policies and Islamist Radicalism." In Political Islam: Revolution, Radicalism or Reform. Edited by J.L. Esposito. Boulder: Lynne Rienner, 1997. 17-32.

Aspinall, Edward. Islam and Nation: Separatist Rebellion in Aceh, Indonesia. Stanford: Stanford University Press, 2009.

Ayata, Bilgin and Serra Hakyemez. "The AKP's Engagement with Turkey's Past Crimes: An Analysis of PM Erdoğan's 'Dersim Apology'.” Dialectical Anthropology 37, no. 1 (2013): 131-143.

Ayoob, Mohammed. "Political Islam: Image and Reality." World Policy Journal 21, no. 3 (2004): 1-14.

Aytaç, S. Erdem and Ziya Öniş. "Varieties of Populism in a Changing Global Context: The Divergent Paths of Erdoğan and Kirchnerismo." Comparative Politics 47, no. 1 (2014): 41-59.

Ayubi, Nazih. Political Islam: Religion and Politics in the Arab World. London and New York: Routledge, 2003. Barata, Maria João and Valentina Bartolucci. "Delegitimisation of Identity as a Political Strategy: The Moroccan Official Discourse about the Polisario Front." SSRN (2009). http://papers.ssrn.com/sol3/ papers.cfm?abstract_id=2362007.

Bayat, Asef. "Activism and Social Development in the Middle East." International Journal of Middle East Studies 34, no. 1 (2002): 1-28.

Boukhars, Anouar and Ali O. Amar. "Trouble in the Western Sahara." The Journal of the Middle East and Africa 2, no. 2 (2011): 220-234.

Brocker, Manfred and Mirjam Künkler. "Religious Parties Revisiting the Inclusion-Moderation Hypothesis 1: Introduction." Party Politics 19, no. 2 (2013): 171-186.

Cammett, Melani and Pauline Jones Luong. "Is There an Islamist Political Advantage?" Annual Review of Political Science 17 (2014): 187-206. 
Candaş, Ayşen and Ayşe Buğra. "Solidarity among Strangers: A Problem of Coexistence in Turkey." Constellations 17, no. 2 (2010): 293-311.

Chalk, Peter. "Separatism and Southeast Asia: The Islamic Factor in Southern Thailand, Mindanao, and Aceh." Studies in Conflict and Terrorism 24, no. 4 (2001): 241-269.

Clark, Janine A. Islam, Charity, and Activism: Middle-Class Networks and Social Welfare in Egypt, Jordan, and Yemen. Bloomington: Indiana University Press, 2004.

Davis, Nancy Jean and Robert V. Robinson. Claiming Society for God: Religious Movements and Social Welfare in Egypt, Israel, Italy, and the United States. Bloomington: Indiana University Press, 2012.

Denoeux, Guilain. "The Forgotten Swamp: Navigating Political Islam.” Middle East Policy 9, no. 2 (2002): 56-81.

Ekmekçi, Faruk.“Understanding Kurdish Ethnonationalism in Turkey: Socio-economy, Religion, and Politics." Ethnic and Racial Studies 34, no. 9 (2011): 1608-1617.

Entessar, Nader. "The Kurds in Post-revolutionary Iran and Iraq." Third World Quarterly 6, no. 4 (1984): 911-933.

Esen, Berk and Şebnem Gümüşçü. "Rising Competitive Authoritarianism in Turkey." Third World Quarterly 37, no. 9 (2016): 1581-1606.

Esposito, John L. The Islamic Threat: Myth or Reality. Oxford and New York: Oxford University Press, 1992.

García-Rivero, Carlos and Hennie Kotzé. "Electoral Support for Islamic Parties in the Middle East and North Africa." Party Politics 13, no. 5 (2007): 611-636.

Gümüşçü, Şebnem and Deniz Sert. "The Power of the Devout Bourgeoisie: The Case of the Justice and Development Party in Turkey." Middle Eastern Studies 45, no. 6 (2009): 953-968.

Günay, Onur. "Toward a Critique of Non-Violence." Dialectical Anthropology 37, no. 1 (2013): 171-182.

_. "In War and Peace: Shifting Narratives of Violence in Kurdish Istanbul." American Anthropologist 121, no. 3 (2019): 554-567.

Gürses, Mehmet. "Islamists, Democracy and Turkey: A Test of the Inclusion-Moderation Hypothesis." Party Politics 20, no. 4 (2014): 646-653.

_. "Is Islam a Cure for Ethnic Conflict? Evidence from Turkey." Politics and Religion 8, no. 1 (March 2015): 135-154.

Gürses, Mehmet and Nicolas Rost. "Religion as a Peacemaker? Peace Duration after Ethnic Civil Wars." Politics and Religion 10, no. 2 (2016): 1-24.

Harik, Judith. The Public and Social Services of the Lebanese Militias. Oxford: Centre for Lebanese Studies, 1994.

Harrigan, Jane and Hamed El-Said. Economic Liberalisation, Social Capital and Islamic Welfare Provision. Houndmills and New York: Palgrave Macmillan, 2009.

Hassan, Hussein D. "Iran: Ethnic and Religious Minorities." CRS Report for Congress, Order Code RL34021. https://fas.org/sgp/crs/mideast/RL34021.pdf.

Houston, Christopher. "Civilizing Islam, Islamist Civilizing? Turkey's Islamist Movement and the Problem of Ethnic Difference." Thesis Eleven 58, no. 1 (1999): 83-98.

_. Islam, Kurds and the Turkish Nation State. Oxford and Gordonsville: Bloomsbury Academic, 2003. IPSOS. "2015 Genel Seçim Sandık Sonrası Araştırması.” June 8, 2015. http://www.arastirmakutuphanesi. com/wp-content/uploads/2015/06/Ipsos_SandikSonrasi_CNNTURK-web2.pdf.

Ismail, Salwa. "The Paradox of Islamist Politics." Middle East Report 221 (2001): 34-39.

Karakoç, Jülide. "The Failure of Indirect Orientalism: Islamic State." Critique 42, no. 4 (2014): 597-606.

Keddie, Nikki R. "The Revolt of Islam, 1700 to 1993: Comparative Considerations and Relations to Imperialism." Comparative Studies in Society and History 36, no. 3 (July 1994): 463-487.

Kepel, Gilles. Jihad: The Trail of Political Islam. Translated by Anthony F. Roberts. Cambridge, MA: Belknap, 2002. Kingsbury, Damien. "The Free Aceh Movement: Islam and Democratisation." Journal of Contemporary Asia 37, no. 2 (2007): 166-189.

KONDA. Kürt Meselesi'nde Algı ve Beklentiler. İstanbul: Illetişim, 2011.

—. "7 Haziran Sandık ve Seçmen Analizi." KONDA, June 2015. https://konda.com.tr/tr/rapor/7haziran-sandik-ve-secmen-analizi/.

—_. "1 Kasım Sandık ve Seçmen Analizi Raporu." KONDA, December 2015. https://konda.com.tr/tr/ rapor/1-kasim-sandik-ve-secmen-analizi/. 
Lewis, Bernard. "The Roots of Muslim Rage." The Atlantic 266, no. 3 (1990): 47-60.

Lia, Brynjar. The Society of the Muslim Brothers in Egypt: The Rise of an Islamic Mass Movement, 1928-1942. Reading: Ithaca Press, 1998.

Mandaville, Peter. Global Political Islam. Oxford and New York: Routledge, 2010.

Masoud, Tarek. Counting Islam: Religion, Class, and Elections in Egypt. Cambridge: Cambridge University Press, 2014.

Meyersson, Erik. "How Turkey's Social Conservatives Won the Day for HDP." Erik Meyersson, June 8, 2015. http://erikmeyersson.com/2015/06/08/how-turkeys-social-conservatives-won-the-day-for-hdp/.

_. "Kinky Voting and Turkey's 'Sultans of Swing'." Erik Meyersson, November 9, 2015. http:// erikmeyersson.com/2015/11/09/kinky-voting-and-turkeys-sultans-of-swing/.

Miller, Judith. "The Challenge of Radical Islam." Foreign Affairs 72, no. 2 (1993): 43-56.

Mishal, Shaul and Avraham Sela. The Palestinian Hamas: Vision, Violence, and Coexistence. New York: Columbia University Press, 2006.

Misra, Ashutosh. "Rise of Religious Parties in Pakistan: Causes and Prospects." Strategic Analysis 27, no. 2 (2003): 186-215.

Mujani, Saiful and R. William Liddle. "Muslim Indonesia's Secular Democracy." Asian Survey 49, no. 4 (2009): 575-590.

Mutlu, Servet. "The Economic Cost of Civil Conflict in Turkey." Middle Eastern Studies 47, no. 1: 63-80.

Naqvi, Ali Mohammed. Islam and Nationalism. Translated by Alaedin Pazargadi. Tehran: Islamic Propagation Organization, 1984.

Nasr, Seyyed Vali Reza. "The Rise of 'Muslim Democracy'." Journal of Democracy 16, no. 2 (2005): 13-27.

Noor, Farish A. "Blood, Sweat and Jihad: The Radicalization of the Political Discourse of the Pan-Malaysian Islamic Party (PAS) from 1982 Onwards." Contemporary Southeast Asia: A Journal of International and Strategic Affairs 25, no. 2 (2003): 200-232.

Ocakli, Feryaz. "Notable Networks: Elite Recruitment, Organizational Cohesiveness, and Islamist Electoral Success in Turkey." Politics \& Society 43, no. 3 (2015): 385-413.

Office of the United Nations Commissioner for Human Rights (OHCHR). "Report on the Human Rights Situation in South-East Turkey: July 2015 to December 2016.” February 2017. https://www.ohchr. org/Documents/Countries/TR/OHCHR_South-East_TurkeyReport_10March2017.pdf.

Öniş, Ziya. "The Political Economy of Islamic Resurgence in Turkey: The Rise of the Welfare Party in Perspective." Third World Quarterly 18, no. 4 (1997): 743-766.

_. "The Political Economy of Turkey's Justice and Development Party." In The Emergence of a New Turkey: Democracy and the AK Parti. Edited by M. Hakan Yavuz. Salt Lake City: University of Utah Press, 2006. 207-234.

Öz, Talha. "Vote Transitions in Turkish General Elections (2011-2015)." Talha Öz, June 9, 2015. http://talhaoz.com/?p=735.

Pepinsky, Thomas B., R. William Liddle, and Saiful Mujani. "Testing Islam's Political Advantage: Evidence from Indonesia." American Journal of Political Science 56, no. 3 (2012): 584-600.

Roy, Olivier. The Failure of Political Islam. Translated by Carol Volk. London: I.B. Tauris, 1994.

Sadowski, Yahya. "Political Islam: Asking the Wrong Questions?" Annual Review of Political Science 9, no. 1 (2006): 215-240.

Said, Edward. Orientalism. New York: Pantheon, 1978.

Sakallığlu, Ümit Cizre. "Kurdish Nationalism from an Islamist Perspective: The Discourses of Turkish Islamist Writers." Journal of Muslim Minority Affairs 18, no. 1, (1998): 73-89.

SAMER. "Seçmenlerin Toplumsal Profili ve Siyasal Eğilimleri Sınıf, Toplumsal Cinsiyet, Etnisite, Din, İdeoloji ve Gezi Olayları.” 2014. https://docplayer.biz.tr/7160826-Secmenlerin-toplumsal-profili-ve-siyasalegilimleri-sinif-toplumsal-cinsiyet-etnisite-din-ideoloji-ve-gezi-olaylari.html.

Samii, A. William. "The Nation and Its Minorities: Ethnicity, Unity, and State Policy in Iran." Comparative Studies of South Asia, Africa and the Middle East 20, no. 1 (2005): 128-137.

San Martin, Pablo. "Nationalism, Identity and Citizenship in the Western Sahara." The Journal of North African Studies 10, no. 3-4 (2005): 565-592. 
Sarıgil, Zeki and Ömer Fazlıoğlu. "Religion and Ethno-Nationalism: Turkey’s Kurdish Issue." Nations and Nationalism 19, no. 3 (2013): 551-571.

- "Exploring the Roots and Dynamics of Kurdish Ethno-nationalism in Turkey." Nations and Nationalism 20, no. 3 (2014), 436-458.

Sater, James N. Morocco: Challenges to Tradition and Modernity. Oxford and New York: Routledge, 2009.

Shadid, Anthony. Legacy of the Prophet: Despots, Democrats, and the New Politics of Islam. New York: Basic Books, 2002.

Sokhey, Sarah Wilson and A. Kadir Yıldırım. "Economic Liberalization and Political Moderation: The Case of Anti-System Parties." Party Politics 19, no. 2 (2013): 230-255.

Somer, Murat and Gitta Glüpker-Kesebir. "Is Islam the Solution? Comparing Turkish Islamic and Secular Thinking toward Ethnic and Religious Minorities." Journal of Church and State 58, no. 3 (2016): 529-555.

Spector, Samuel J. "Negotiating Free Association between Western Sahara and Morocco: A Comparative Legal Analysis of Formulas for Self-Determination." International Negotiation 16, no. 1 (2011): 109-135.

Tezcür, Güneş Murat. Muslim Reformers in Iran and Turkey: The Paradox of Moderation. Austin: University of Texas Press, 2010.

Thachil, Tariq. "Elite Parties and Poor Voters: Theory and Evidence from India." American Political Science Review 108, no. 2 (2014): 454-477.

Trager, Eric. "The Unbreakable Muslim Brotherhood: Grim Prospects for a Liberal Egypt.” Foreign Affairs 90, no. 5 (2011): 114-126.

Tuğal, Cihan. Passive Revolution: Absorbing the Islamic Challenge to Capitalism. Stanford: Stanford University Press, 2009.

Turner, Bryan S. "Class, Generation and Islamism: Towards a Global Sociology of Political Islam." The British Journal of Sociology 54, no. 1 (2003): 139-147.

Türkmen, Gülay. "Negotiating Symbolic Boundaries in Conflict Resolution: Religion and Ethnicity in Turkey's Kurdish Conflict." Qualitative Sociology 41, no. 4 (2018): 569-591.

Ucko, David H. "'The People are Revolting': An Anatomy of Authoritarian Counterinsurgency." Journal of Strategic Studies 39, no. 1 (2016): 29-61.

Walsh, John. "Egypt's Muslim Brotherhood: Understanding Centrist Islam." Harvard International Review 24, no. 4 (2003): 32-36.

Wedeen, Lisa. “Conceptualizing Culture: Possibilities for Political Science." American Political Science Review 96, no. 4 (December 2002): 713-728.

White, Jenny B. Islamist Mobilization in Turkey: A Study in Vernacular Politics. Seattle: University of Washington Press, 2002.

Wiktorowicz, Quintan. Islamic Activism: A Social Movement Theory Approach. Bloomington: Indiana University Press, 2004.

Yeğen, Mesut. "The 2011 Elections and the Kurdish Questions." Insight Turkey 13, no. 4 (2011): 147-169. Yörük, Erdem. "Welfare Provision as Political Containment: The Politics of Social Assistance and the Kurdish Conflict in Turkey." Politics \& Society 40, no. 4 (2012): 517-547.

Yörük, Erdem and Hişyar Özsoy. "Shifting Forms of Turkish State Paternalism Toward the Kurds: Social Assistance as 'Benevolent' Control.” Dialectical Anthropology 37, no. 1 (2013): 153-158. 